\title{
Camptodactyly of fingers
}

INSERM

\section{Source}

INSERM. (1999). Orphanet: an online rare disease and orphan drug data base.

Camptodactyly of fingers. ORPHA:295016

Camptodactyly of fingers is a rare, genetic, non-syndromic, congenital limb malformation disorder characterized by a painless, non-traumatic, non-neurog enic, often bilateral, permanent flexion contracture at the proximal interphalangeal joint of a postaxial finger, resulting in permanent volar inclination of the affected digit. The fifth finger is always involved, but additional digits might also be affected. 